Article

\title{
Experimental Investigation of the Use of Waste Mineral Oils as a Fuel with Organic-Based Mn Additive
}

\author{
Bülent Özdalyan ${ }^{1}$ (i) and Recep Ç. Orman ${ }^{2, *}$ (i) \\ 1 Department of Mechanical Engineering, Karabük University, Karabük 78050, Turkey; ozdalyan@gmail.com \\ 2 Department of Automotive Technology, Gazi University, Ankara 06980, Turkey \\ * Correspondence: recepcagriorman@gmail.com; Tel.: +90-312-354-84-01
}

Received: 12 May 2018; Accepted: 5 June 2018; Published: 11 June 2018

\begin{abstract}
The heat values of waste mineral oils are equal to the heat value of the fuel oil. However, heat value alone is not sufficient for the use of waste minerals oils as fuel. However, the critical physical properties of fuels such as density and viscosity need to be adapted to the system in order to be used. In this study, the engine oils used in the first 10,000 km of the vehicles were used as waste mineral oil. An organic-based Mn additive was synthesized to improve the properties of the waste mineral oil. It was observed that mixing the Mn additive with the waste mineral oil at different doses $(4,8,12$, and $16 \mathrm{ppm})$ improves the viscosity of the waste oil and the flash point. The resulting fuel was evaluated for emission using different loads in a $5 \mathrm{~kW}$ capacity generator to compare the fuel with standard diesel fuel and to determine the effect of Mn addition. In the experimental study, it was observed that the emission characteristics of the fuel obtained from waste mineral oil were worse than diesel fuel, but some improvement was observed with Mn addition. As a result, we found that the use of waste mineral oils in engines in fuel standards was not appropriate, but may be improved with additives.
\end{abstract}

Keywords: waste mineral oil; Mn additive; engine performance; emission

\section{Introduction}

Development of alternative fuels instead of rapidly consuming fossil-based fuels, especially for internal combustion engines, is an important and critical issue for humanity, both for economic and environmental reasons [1]. It is possible to find many studies on the use of vegetable or animal waste oils instead of diesel fuel by esterification. These fuels, which are called biodiesel fuels, are very important for the use of weft oil as an alternative fuel [2,3]. Nowadays, the disposal of used or waste vegetable oils is an environmental and legal necessity, and the use of these wastes as fuel seems to be an important energy potential $[4,5]$. The use of oil produced from waste tire as fuel, and the production of synthetic diesel fuel from renewable sources are at least as popular research topics as biodiesel [6-10]. The disposal of waste mineral oils is an important question, just like the disposal of vegetable oils [11]. A large part of these waste engine oils is petroleum-based products, and approximately $1.2 \%$ of annual petroleum consumption is composed of engine oil. The heat values of waste mineral oils are equal to the heat value of the fuel oil (42-44 MJ/ kg) [12]. Although these waste oils are petroleum-based, their blending with direct fuels and/or existing fuels is prohibited or restricted in many countries, especially due to their environmental impact. However, the collection of these waste oils in a controlled manner is another legal requirement [13].

During combustion and chemical processing, the physical properties of engine oil must not change as much as possible. However, due to mechanical movement, a high temperature, and particulate 
matter, engine oil gradually loses its properties, and engine oil therefore needs to be replaced in a determined period. Thus, waste oil is formed [14]. Due to the economic situation after the Second World War, the recycling of these waste oils emerged in order to save raw materials. In the aftermath of the Second World War, as a result of refinery development in France and international stock exchanges, new sources for the supply of petroleum-based oils to the market were introduced, and the acquisition of competitive value, that is, energy saving, was promoted by considering energy saving [15]. Today, with the awareness of environmental hazards, many developed and developing countries have been legitimized with the idea of collecting waste mineral oil, which started with economic reasons in advance [14].

According to the European Union's "Waste Directive", it is foreseen that the separate collection of waste oils has a vital importance in terms of proper waste management and the prevention of harm from unsuitable treatment environments judging by analyses according to the life cycle. According to the "Waste Management Hierarchy" specified in the Directive, it is emphasized that the most beneficial application for the environment should be given priority. Waste must be reduced, recycled, recycled as raw material, recovered as energy, and ultimately disposed of at the source according to priority order [16].

There is no obstacle to the use of waste oil as fuel when environmental restrictions are adhered to. Depending on the conditions of use, waste engine oils contain metals and derivatives and some ash. Such materials can be removed from waste oil by various filtration methods. However, for the use of waste oils as direct fuel, only the application of the filtration process may not be sufficient. Depending on the use of waste oil as fuel, some of the physical properties of the oil should be made compatible with the system to be used. While work on the use of waste oil as a direct fuel is ongoing, it is also possible to mix it with existing fuels [17].

There are many studies on the use of waste engine oils as fuel in engines. When these studies are examined, it is observed that gasoline-like or diesel-like fuels are obtained from waste engine oils by pyrolytic distillation in general. Arpa et al. studied pyrolytic distillation and investigated the thermal and physical properties of fuels after mixing the sodium carbonate, zeolite, and lime additives (catalysts) in filtered waste oil at certain percentages [15]. Balat, in his work, blended perlite and wood ash in filtered oil for pyrolytic distillation. Balat mentioned that waste engine oils could be used in gasoline engines as an alternative fuel [18]. Balat et al. have stated that by mixing pyrolysis with filtered wood waste ash, alternative gasoline or diesel fuel can be obtained [19]. Demirbaş mentions that waste engine oils can produce olefin-rich oils at elevated temperatures and that these oils can be obtained with gasoline-like fuel with 96 octane number of prolyl in the presence of an aluminum catalyst [20]. Kannan et al. note that zeolite can be reformed in the presence of a catalyst to convert waste engine oils into a fuel that is suitable for diesel engines. For this, the physical and thermal properties of the oil obtained after reforming are compared with those of diesel fuel. The resulting oil is said to be usable in diesel engines [21]. Maceiras et al. have converted fuels by pyrolytic distillation in the presence of sodium hydroxide and sodium carbonate catalyst, which can be used in waste engine oil diesel engines. With this study, it has been found that the conversion of waste engine oil to diesel fuel can be achieved by pyrolytic distillation in the presence of $2 \%$ sodium carbonate [22]. In their study, Prabakaran and colleagues examined the physical and thermal properties of waste engine oil reformed in acetic acid and clay compartments by diesel fuel at various ratios. The resulting mixture was tested in a fuel diesel engine and was reported to reduce specific fuel consumption (sfc), nitrogen oxide (NOx), and hydrocarbon (HC) emissions [23]. Zandi et al. studied the catalytic conversion of waste engine oil to diesel engines in the presence of the nano- $\mathrm{CeO}_{2} / \mathrm{SiO}_{2}$ catalyst synthesized by different analytical methods and examined the physical and thermal properties of the fuel [24]. Aburas et al. describe the use of pyrolysis and cracking methods to convert waste engine oils to reusable products such as gasoline, diesel, and fuel oil. In the study conducted, calcium oxide was used as an additive in various proportions [25]. 
Unlike the studies in the literature, we investigated the possibility of using diesel fuel as a fuel mixed with organic-based Mn addition only after the mechanical filtration process without any heat treatment in the waste mineral oil in this study. We aimed to investigate the engine performance and emissions of waste engine oil as a fuel in diesel engines by mixing it with a series of physical filtration and organic-based Mn additives.

\section{Materials and Method}

\subsection{Waste Mineral Oil}

Waste mineral oils are generally divided into two groups: waste mineral engine (or automotive) oil and waste mineral industrial oil. Waste metal engine oils are considered different from industrial waste oils due to the usage conditions. Waste mineral engine oils operate under more severe conditions such as high temperature, high pressure, and combustion. Waste engine oils are called black waste oil due to their color. Waste oils used in machines that are not combustible are called clean waste oil [26].

Mineral oils are collected as waste oil after use. These collected oils have different characteristic oils that are manufactured from different base materials, manufactured with different additives, and worked under different conditions [27]. Such sorting of waste oils is a difficult and costly task. For this reason, waste metallic engine oils are generally recycled by being characterized as a single feature [28].

The waste oil used in this study was waste lubricant after the first 10,000 km of the vehicles, which was called the first run-off oil. The run-off oil does not carry a different oil feature. Since the purpose of the work is to examine the availability of waste mineral oils as direct fuel, filtration with only a paper filter has been done so that the waste mineral oils can be cleaned after collecting the large particles.

\subsection{Organic-Based Mn Additive and Fuel}

The method of synthesizing organic-based additives has been described in detail in earlier works [29-35]. For the synthesis of the organic-based Mn additive, in a one liter reactor equipped with a reflux condenser, abietic acid (resin acid) and manganese dioxide $\left(\mathrm{MnO}_{2}\right)$ were introduced into the reaction mixture at $150{ }^{\circ} \mathrm{C}$ in an oiled medium with the aid of a magnetic stirrer, and an organic-based manganese compound was synthesized. The mass ratio for $\mathrm{MnO}_{2}$, abietic acid and oil was 1:2.9:6.5. The additive, which was converted into solution with the alcohol and hydrocarbon compounds, was mechanically drained at different concentrations and dosed with the mineral oil $(4,8,12$, and $16 \mathrm{ppm})$ for one day. Ethanol was added to ensure the solubility of the mixture. For the determination of the kinematic viscosity of the obtained fuel, the Engler viscometer was determined by the Cleveland open cup method for flash point determination.

\subsection{Experimental Setup}

A diesel generator with a maximum power of $5 \mathrm{~kW}$ was used to determine the effects on the diesel engine of the fuel prepared by dosing the Mn-based additive to the waste mineral oil. The diesel engine used in the generator can generate $6.4 \mathrm{~kW}$ of power at $3000 \mathrm{rpm}$ [36]. The characteristics of the diesel generator are as follows (Table 1 ).

The generator used in the experiments was operated at a fixed $3000 \mathrm{rpm}$ motor speed, and this speed was regulated according to the alternator load. However, when the test fuel was changed, there was some change in this constant speed and the generator had difficulties regulating this speed. Small adjustments had to be made for this. In the experiments, six resistive loads were formed with electrical resistances in the range of $0.75-4.5 \mathrm{~kW}$ (Figure 1). 
Table 1. General characteristics of the generator used in the experiment [36].

\begin{tabular}{cc}
\hline Specification & Explanation \\
\hline Generator model & P-7500 DE \\
Engine model & $186-\mathrm{FAE}$ \\
Alternator type & Monophase \\
Max alternator power & $5 \mathrm{~kW}$ \\
Contunious alternator power & $4.5 \mathrm{~kW}$ \\
Alternator speed & $3000 \mathrm{rpm}(50 \mathrm{~Hz})$ \\
Alternator mechanical efficiency & 0.8 \\
Mean fuel consumption & $2.23 \mathrm{~L} / \mathrm{h}$ \\
Max engine power & $6.4 \mathrm{~kW} 3000 \mathrm{rpm}$ \\
Contunions engine power & $5.7 \mathrm{~kW} 3000 \mathrm{rpm}$ \\
Cooling system & Air cooled \\
Intake system & Natural aspirated \\
Stroke $\times$ Diameter & $86 \mathrm{~mm} \times 72 \mathrm{~mm}$ \\
Compression ratio & $19: 1$ \\
Stroke volume & $418 \mathrm{~cm}^{3}$ \\
\hline
\end{tabular}

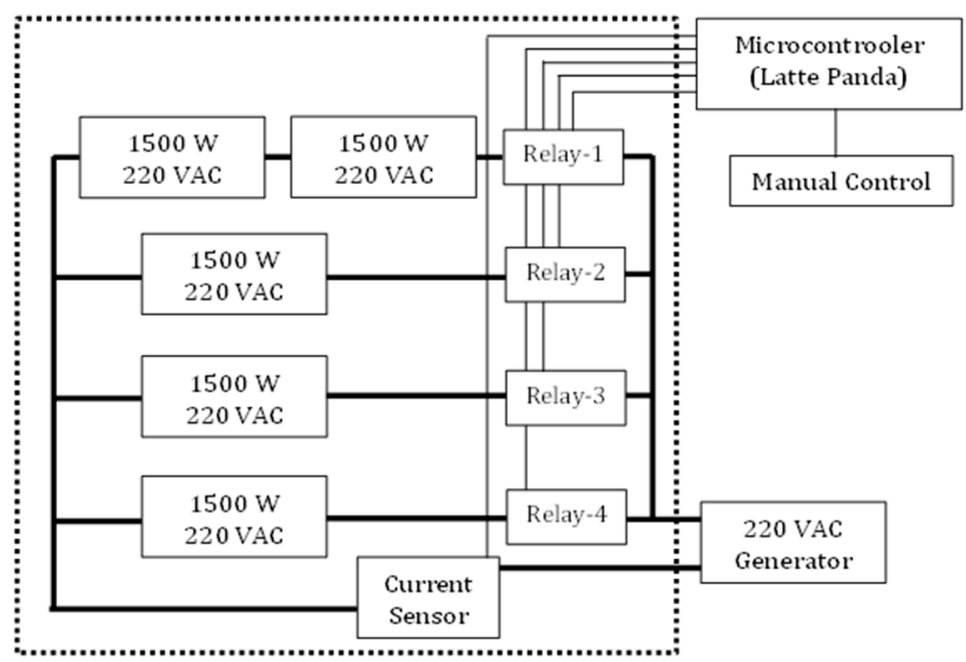

Figure 1. Resistive load cycle.

The heater at $1500 \mathrm{~W}$ rated current drew approximately 6.8 A current at $220 \mathrm{~V}$ mains voltage, and the resistance value of this heater was approximately $32 \mathrm{ohms}$. When two $1500 \mathrm{~W}$ nominal heaters were connected in series, the resistance in the circuit doubled and the current drawn was reduced by half. In this case, the total power of these two heaters connected in series was $750 \mathrm{~W}$. When two $1500 \mathrm{~W}$ nominal heaters were connected in parallel, the resistance in the circuit was reduced by half and the total current drawn up doubled. In this case, the total power of these two heaters connected in parallel will be $3000 \mathrm{~W}$. Similar calculations can be made for other situations. The power values here were governed by whether the relays connected to the microprocessor card were open or closed. For example, power was $750 \mathrm{~W}$ when relay 1 was on, power was $1500 \mathrm{~W}$ when relay 2 was on, and power was $2250 \mathrm{~W}$ when relay 2 was on. Effective engine power was determined by the proportion of this reactive load alternator compared to the fixed mechanical efficiency. The generator was known to have a mechanical efficiency of $80 \%$.

$$
\begin{gathered}
P_{e, \text { corrected }}=k \cdot P_{\text {e,exp }} \\
k=\left(\frac{101.3}{P_{\text {amb. }}(\mathrm{kPa})}\right)^{0.65}\left(\frac{T_{\text {exp. }}(\mathrm{K})}{293}\right)^{0.5}
\end{gathered}
$$


Experiments were carried out at a temperature of $22{ }^{\circ} \mathrm{C}(295 \mathrm{~K})$ and a pressure of $91 \mathrm{kPa}$. Throughout the experiments, these conditions were not changed. Accordingly, the correction coefficient was calculated as $k=1.075$. In the experiments, volumetric fuel measurements were made. The time of use of the $20 \mathrm{~mL}$ fuel with the graduated container was measured, and the hourly mass fuel consumption was then calculated.

$$
\dot{m}_{f}[\mathrm{~g} / \mathrm{h}]=\frac{72 \cdot \rho_{f}[\mathrm{~g} / \mathrm{L}]}{t[\mathrm{~s}]}
$$

$\rho_{f}$ is the fuel density and the fuel densities used in the experiment were measured by a $10.350 \mathrm{~mL}$ calibrated density bottle (pycnometer) at $20{ }^{\circ} \mathrm{C}$. The densities of the fuels used in the experiments were calculated as $0.810 \mathrm{~g} / \mathrm{L}$ and $0.851 \mathrm{~g} / \mathrm{L}$ for the diesel fuel and the additive waste mineral oil, respectively. Specific fuel consumption was calculated by the ratio of fuel consumption to engine power. In order to operate the generator at a constant speed, a rotary encoder was installed at the rear of the diesel engine, and small adjustments were made to maintain the engine speed constantly under control. The oil temperature was used as a reference for the engine's stable operating conditions, since the oil temperature in air-cooled engines was considered as a more sensitive measuring point than the body temperature.

It was expected that the oil temperature would be stabilized by waiting approximately $25 \mathrm{~min}$ after starting the generator, and this was expected for other loads as well. The oil temperature measurement was made by using the universal temperature indicator with the PT-100 temperature sensor installed instead of the oil filling plug. In the experiments, emission measurement was limited by particle measurement and smoke density. The amount of particulate matter and smoke concentration values used as emission indicators of diesel engines was found to be sufficient since the intended use of the engine was limited to the use of waste engine oils in diesel engines. The aim of the emission measurement here was to compare the contribution prepared for the waste oil in terms of the amount of particulate and smoke density, which is an emission criterion for diesel engines. For this reason, no measurement with a gas analyzer was needed. The emission instrument used in the experiments could measure the smoke intensity at $0-100 \%\left(\right.$ or $1-20 \mathrm{~m}^{-1}$ ) and the amount of particles at $0-1000 \mathrm{mg} / \mathrm{m}^{3}$. The schematic representation of the experimental setup is as shown in Figure 2.

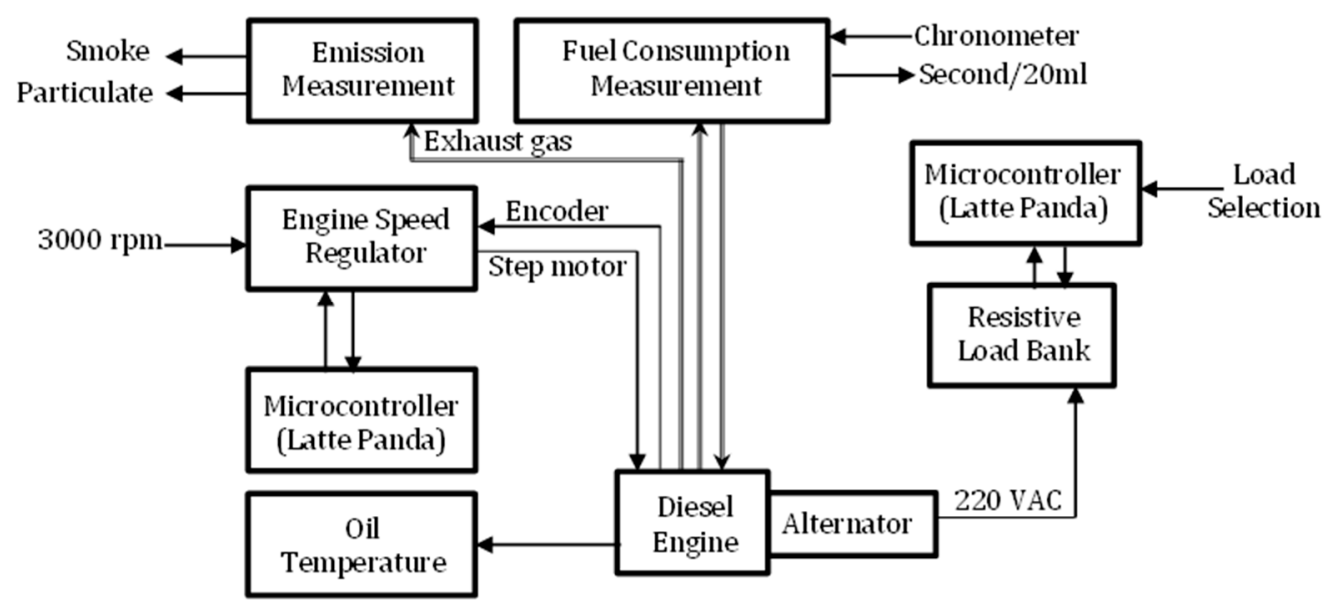

Figure 2. Experimental setup.

The resistive load bank and microcontroller are shown in Figures 1 and 2 in detail. The resistive load bank was directly connected to the electrical power socket of the generator. To operate the engine at a constant speed of $3000 \mathrm{rpm}$, a simple step motor was placed on the fuel setting mechanism, and the position of the step motor was changed according to the engine speed value that was read 
from the encoder. For any engine load, a period of time was required before the engine speed could be stabilized.

In this study, the change in the properties of the waste mineral oil was investigated primarily by the dosing of the additive. The experimental set was then used as standard diesel fuel, unmixed waste mineral oil, and standard diesel engine fuel of waste mineral oil dosed with $16 \mathrm{ppm}$ of organic-based Mn additive. The results of the experiments were used to determine the effect of the additive and the use of the waste mineral oil as fuel in the diesel engines by obtaining emission and fuel consumption values.

\subsection{Error Analysis and Uncertainties}

In the present study, error analysis of the measured and derived values was conducted, and uncertainties were also determined by using Kline and Mc. Clintock's method [37]. As each value was measured three times, student's t-distribution was applied to the experimental data. Through the evaluation of measured data, uncertainty intervals of fuel consumption, stable oil temperature, smoke density, and particle matter values were determined at the levels of $(0.1-0.5) \%$, $(0.08-0.6) \%$, $(1.11-3.5) \%$, and $(0.1-6.5) \%$, respectively. From these results, it can be concluded that the probable uncertainties in the measuring of the principle values and in the derived values would not significantly affect the uncertainties of the numerical results.

\section{Results and Discussion}

\subsection{Some Properties of the Obtained Test Fuel}

The change in the kinematic viscosity value of the organic-based Mn additive-dosed waste mineral oil with respect to the amount of additive substance in the laboratory is as follows (Figure 3). A high pumping pressure was also needed with high viscosity value. The standard kinematic viscosity of a standard diesel fuel and biodiesel at $40{ }^{\circ} \mathrm{C}$ was in the range of 1.9 to $4.5 \mathrm{cSt}$ and 3.5 to $5 \mathrm{cSt}$, respectively. [38]. According to the results obtained, although the additive was seen to have a kinematic viscosity lowering effect, it was far from the standard values at present. Only mechanical filtration had been done since the intended use of the waste engine oil was the target of the work being done. The kinematic viscosity of the waste engine oil could be reduced after different processes, but this increases the operating costs considerably. However, the effect of Mn addition on the kinematic viscosity after a certain dose was very small.

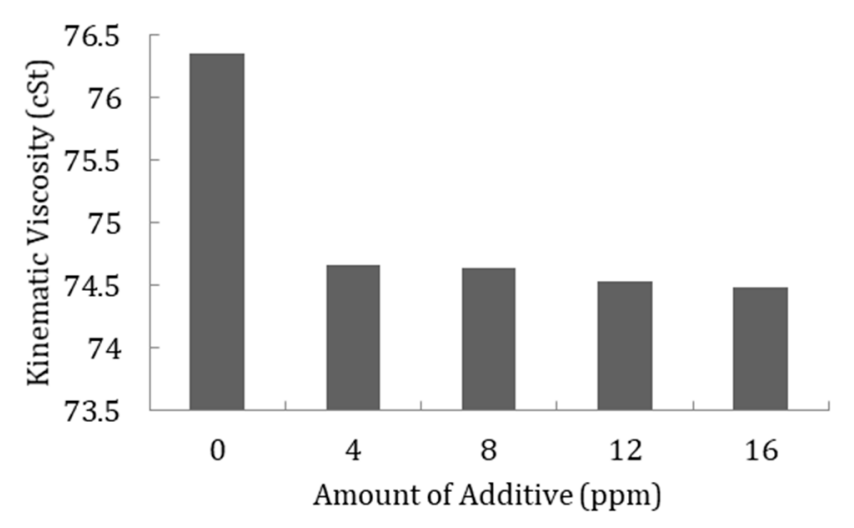

Figure 3. Effect of organic-based Mn additive on kinematic viscosity.

If a process for reducing viscosity was performed independently of the additive for waste engine oil, the kinematic viscosity of the fuel obtained with the additive material would be approximated to the standards. 
The minimum temperature at which there is a sufficient concentration of evaporated fuel in the air for the flame to propagate after an ignition source has been introduced, is defined as flash point. Essentially, the flash point is the lowest temperature at which there is sufficient fuel vapor to give a momentary flash. It is one of the major flammability indices used to establish the fire and explosion hazards of liquids. The minimum limit values for the flash point are standard. When the effect of the manganese additive on the ignition point of waste motor oil was examined, it was seen that the additive was a reducing effect of the flash point (Figure 4).

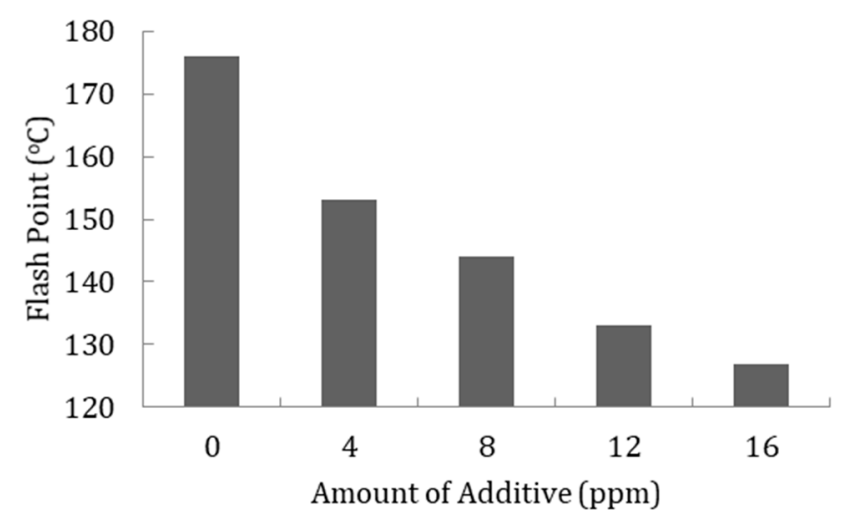

Figure 4. Effect of organic-based Mn additive on flash point.

The results from these laboratory tests were compared according to the EN 590 standard and were found to be close to the diesel fuel standards with the additive [39]. As a result of all these experiments, it was decided to use the 16 ppm organic-based Mn additive-dosed waste oil in the experiments. After this step, engine performance and emissions were compared comparatively using a standard engine, unleaded waste lubricant, and additive waste mineral oil in the engine test set.

\subsection{Effect of Mn Additive on Stable Working Temperature}

In internal combustion engines, depending on the engine load, they work at an average constant temperature with the effect of the cooling system. In air-cooled engines, there are air fins for cooling and a fan that provides air flow to these air fins. The generator used in the experiments has cooling fan blades on the flywheel. The flow rate of the cooling air is constant as the engine is operated at constant speed. In the experiments, the oil temperature was taken as the reference for reaching the stable working (or oil) temperature of the engine. After a short time (approximately $25 \mathrm{~min}$ ), the oil temperature became constant (Figure 5). The air flow rate in the engine cooling system remained constant as the engine was run at a constant speed during all the tests. The stable temperature values obtained in this study varied depending on the fuel characteristic only at a certain load and constant engine speed.

With Mn addition, the stable working temperature decreased by about $5 \%$. The Mn additive had brought the stable working temperature of the waste mineral oil closer to the fuel of the engine. The reduction of the stable working temperature could be shown as the improvement of atomization by the effect of the reduction in viscosity, together with the contribution of Mn additive and accordingly the improvement of the burn. Decreased fuel consumption with a reduced stable working temperature was expected. 


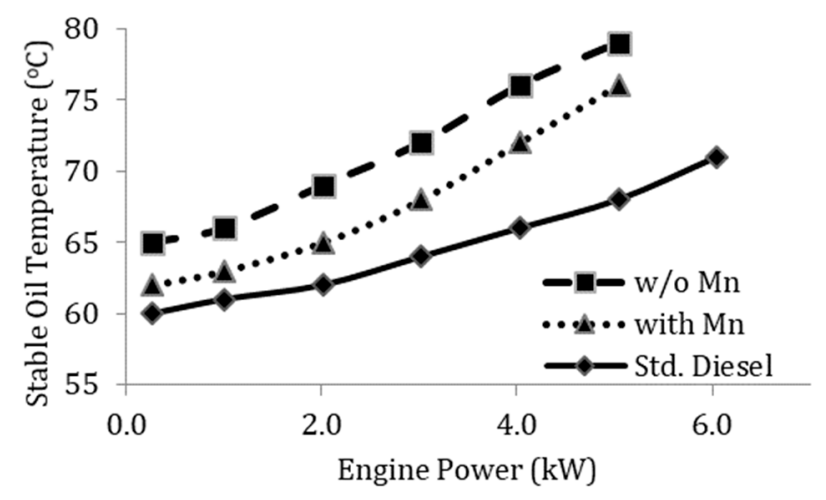

Figure 5. Effect of organic-based Mn additive on stable working temperature.

\subsection{Effect of Mn Additive on Specific Fuel Consumption}

Along with the use of waste mineral oil instead of diesel fuel, there was some decrease in engine speed. The fuel pump has been calibrated to regulate the engine speed again. For this reason, a slight increase in fuel consumption compared to diesel fuel had come to the fore. However, with the Mn additive, it seemed that fuel consumption had decreased somewhat. Along with the Mn additive, there were marked differences in the properties of the fuel such as viscosity and flash point. The effect of these differences was observed in the fuel consumption and specific fuel consumption as well as in the stabilized temperature (Figure 6).

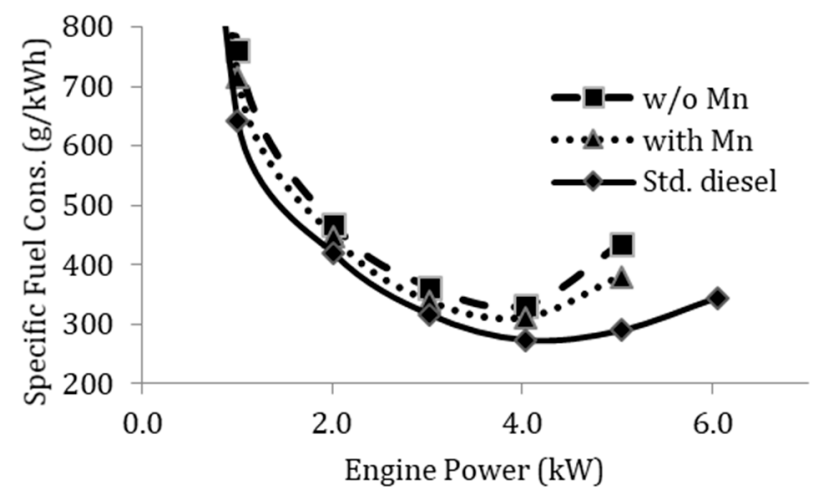

Figure 6. Effect of organic-based Mn additive on specific fuel consumption.

Along with the Mn additive, less fuel was consumed for the same engine load. Given the decrease in stable working temperature, it was shown to decrease in lost heat. Specific fuel consumption, which is another expression of thermal efficiency, decreased with the Mn additive for the same engine power.

\subsection{Effect of Mn Additive on Exhaust Emission}

In diesel engines, emission measurement can be done in detail with a gas analyzer as well as with a diesel smoke tester. However, in this study, a visible darkness was observed in the exhaust smoke with the burning of the waste oil. In diesel engines, the color of the exhaust gas indicates whether the combustion is good or bad, and therefore, only the amount of smoke and particulate matter was measured in this study instead of a detailed gas analysis.

Smoke density is defined as the percentage of nontransparent particles in the exhaust gas that reduce the intensity of the light they pass through when crossing the section [40]. However, another indicator of smoke density is the light absorption coefficient. Smoke density and the light 
absorption coefficient are two emission indices with the same tendency. The light absorption coefficient is limited to $2.5-3 \mathrm{~m}^{-1}$ in diesel engines. These limits also apply to generator engines [41] (Figure 7).

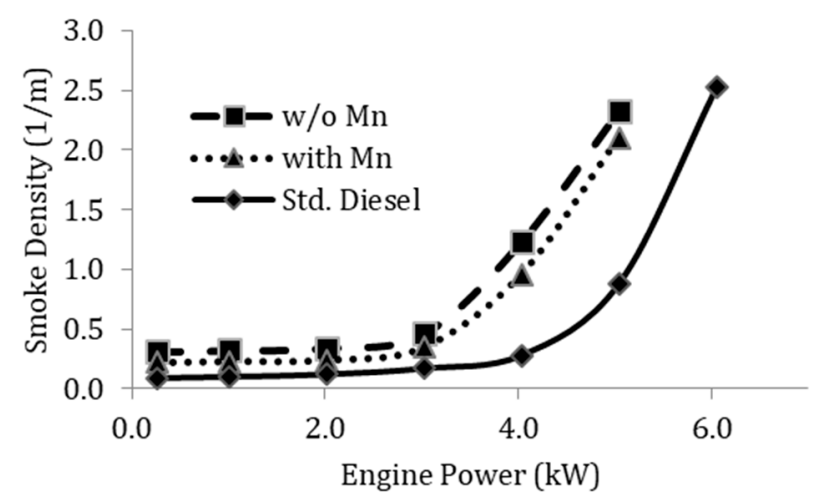

Figure 7. Effect of organic-based Mn additive on smoke density.

The smoke density in experiments with diesel fuel at high engine loads was at normal levels. However, when waste mineral oil was used, it was not possible to measure smoke density because of the tendency of the engine to stop with high engine loads and excessive smoke. Along with the Mn additive, there was a decrease in the smoke density for the same motor load. When the amounts of the particulate matter were compared, it was seen that the Mn addition was also the effect of reducing the amount of the particulate matter (Figure 8).

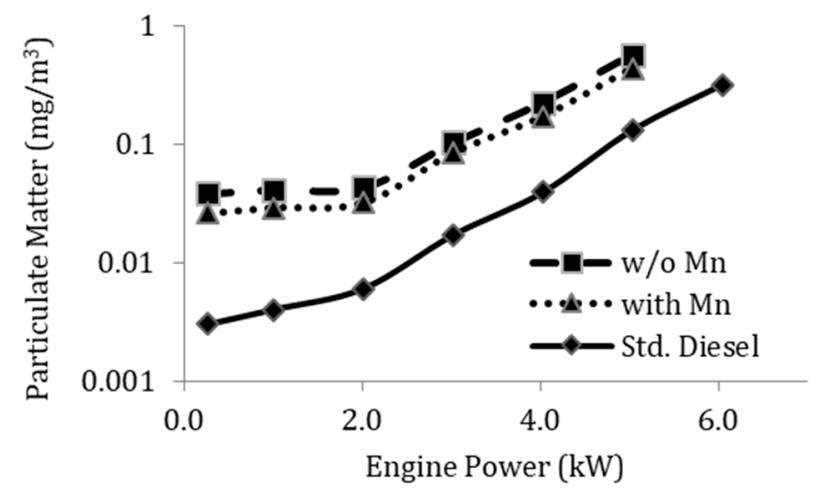

Figure 8. Effect of organic-based Mn additive on particulate matter.

\section{Conclusions}

The effects of organic-based metal additives on engine performance and emissions have been observed in previous studies for biodiesel fuels derived from engine oils and different vegetable and animal oils in previous studies [29-35,42-44]. However, studies on waste mineral oils have focused on the recycling of waste mineral oils after different chemical and mechanical processes [15,22-25]. It is known that the organic-based metal additives synthesized from metal oxides are the effect of improving the properties of fuels used in diesel engines. In this study, the availability of waste mineral oils as a direct fuel in diesel engines was investigated firstly, and then the degree of improvement with organic-based Mn additive material was investigated experimentally using a diesel engine with a power of $6.4 \mathrm{~kW}$. Characteristic measurements were made for a constant speed (3000 rpm) and a variable load $(750 \mathrm{~W}-4.5 \mathrm{~kW})$ with an alternator rated at $5 \mathrm{~kW}$. The kinematic viscosity of the waste oil used was too high compared to standard diesel fuel. High kinematic viscosity caused poor atomization of the fuel, poor combustion, clogging of the injectors, and carbon buildup in the segments. High viscosity required a high pumping pressure and injector spraying was reduced. Experiments 
confirmed this information. It can be said that the effect of Mn addition on the flash point of the waste oil was a positive effect. However, the flash point was generally related to the storage and safety of the fuel. There was no effective change in engine performance. In addition, changes in the flash point did not significantly affect the combustion characteristics. For stable working temperature, the oil temperature was used as a reference. The engine used in the experiments was air-cooled and the cooling load was constant for constant engine speed. For this reason, stable working temperature was a clear indication of engine heat loss. The steady working temperature of standard diesel fuel was even lower, although the stable working temperature with Mn addition decreased somewhat. Since high viscosity negatively affected fuel atomization, the same tendency could be seen in specific fuel consumption. Although the specific fuel consumption of diesel fuel was the lowest in experiments made with fuels with the same thermal values, it cannot be ruled out that the Mn additive has a detrimental effect on the specific fuel consumption of the waste oil.

As a result, when evaluated in terms of engine performance and emissions, it appears that waste mineral oils are not directly usable in diesel engines, especially in systems operating under constant and stable conditions, such as generators. However, with the organic-based Mn addition, the fuel characteristics of the waste mineral oil were closer to the engine. In conjunction with this study, it has been possible, in part, that the organic-based Mn additive can be used in diesel engines. Economically, both waste oil and additives do not cost much to be tested. An economic value can be obtained with the development of this study. As a result of the work being done, it has been understood that critical fuel properties such as viscosity should be improved by passing the waste engine oils through different processes instead of using them directly. In subsequent works, additives of different types of metal oxides can be tested by adjusting the viscosity of the waste engine oil according to the standards. However, a more detailed examination can be made by performing internal cylinder pressure measurement and combustion and heat emission analysis.

Author Contributions: There was an equal contribution of the authors in this study.

Acknowledgments: This study was prepared within the scope of doctoral dissertation conducted at Karabük University (Turkey) Institute of Natural and Applied Sciences. The authors thank the Tanoto (Ford Authorized Service/Ankara/Turkey) authorities for the supply of waste oils. In addition, the authors would like to thank Metin Gürü from Gazi University (Turkey) for their knowledge and experience in the preparation of experimental fuel and its contribution. Thanks also to Emre ARABACI from Mehmet Akif Ersoy University (Turkey) for his intensive support in discussing the experimental results.

Conflicts of Interest: The authors declare no conflicts of interest.

\section{References}

1. Knothe, G.; Krahl, J.; Van Gerpen, J. The Biodiesel Handbook, 2nd ed.; Elsevier: England, UK, 2010; pp. 5-96. [CrossRef]

2. Mahmudul, H.M.; Hagos, F.Y.; Mamat, R.; Adam, A.A.; Ishak, W.F.W.; Alenezi, R. Production, characterization and performance of biodiesel as an alternative fuel in diesel engines-A review. Renew. Sustain. Energy Rev. 2017, 72, 497-509. [CrossRef]

3. Hadiyanto, H.; Widayat, W.; Duma, A. Ultrasound Assisted in Situ Esterification of Rubber Seeds Oil for Biodiesel Production (Research Note). Int. J. Eng. Trans. C 2016, 29, 1635-1641. [CrossRef]

4. Watson, K.S.; Meierhoefer, C.H. Use or disposal of by-products and spent material from the vegetable oil processing industry in the U.S. J. Am. Oil Chem. Soc. 1976, 53, 437-442. [CrossRef]

5. Hassani, M.; Amini, G.; Najafpour, D.; Rabie, M. A two-step Catalytic Production of Biodiesel from waste cooking oil. Int. J. Eng. Trans. C 2013, 26, 563-570. [CrossRef]

6. Samavati, M.; Martin, A.; Santarelli, M.; Nemanova, V. Synthetic Diesel Production as a Form of Renewable Energy Storage. Energies 2018, 11, 1223. [CrossRef]

7. Hamilton, J.; Negnevitsky, M.; Wang, X. Economics of Renewable Energy Integration and Energy Storage via Low Load Diesel Application. Energies 2018, 11, 1080. [CrossRef]

8. Rowhani, A.; Rainey, T.J. Scrap Tyre Management Pathways and Their Use as a Fuel-A Review. Energies 2016, 9, 888. [CrossRef] 
9. Rosa, R.N. The Role of Synthetic Fuels for a Carbon Neutral Economy. C 2017, 3, 11. [CrossRef]

10. Trongkaew, P.; Utistham, T.; Reubroycharoen, P.; Hinchiranan, N. Photocatalytic Desulfurization of Waste Tire Pyrolysis Oil. Energies 2011, 4, 1880-1896. [CrossRef]

11. Lam, S.S.; Russell, A.D.; Chase, H.A. Microwave pyrolysis, a novel process for recycling waste automotive engine oil. Energy 2010, 35, 2985-2991. [CrossRef]

12. Procházka, P.; Hönig, V. Economic Analysis of Diesel-Fuel Replacement by Crude Palm Oil in Indonesian Power Plants. Energies 2018, 11, 504.

13. Mitchell, H. Legislation and regulation of waste oil disposal. Environ. Policy Law 1977, 3, 27. [CrossRef]

14. UNEP United Nations Environment Programme; Tamunaidu, P.; Bhatia, S.; Nasim, M.N.; Pervez, M.S.; Yarasu, R.B.; Aguirre Ortega, B. Waste oils as alternative fuel for diesel engine: A review. Stand. Test Methods Pet. Prod. Lubr. 1998, 5, 30-43. [CrossRef]

15. Arpa, O.; Yumrutas, R.; Demirbas, A. Production of diesel-like fuel from waste engine oil by pyrolitic distillation. Appl. Energy 2010, 87, 122-127. [CrossRef]

16. European Parliament and of the Council. Directive 2008/98/EC. Off. J. Eur. Union 2008, L312, 3-30.

17. Audibert, F. Waste Engine Oils; Elsevier: New York, NY, USA, 2006.

18. Balat, M. Diesel-like fuel obtained by catalytic pyrolysis of waste engine oil. Energy Explor. Exploit. 2008, 26, 197-208. [CrossRef]

19. Balat, M.; Demirbas, M.F.; Balat, M. Pyrolysis of waste engine oil in the presence of wood ash. Energy Sources Part A Recovery Util. Environ. Effects 2009, 31, 1494-1499. [CrossRef]

20. Demirbas, A. Gasoline-like fuel from waste engine oil via catalytic pyrolysis. Energy Sources Part A Recovery Util. Environ. Effects 2008, 30, 1433-1441. [CrossRef]

21. Kannan, M.; Saravanan, C.G. Behaviour of zeolite $4 \mathrm{a}$ in the extraction process of the diesel like fuel obtained from waste engine oil. J. Eng. Sci. Technol. 2015, 10, 1553-1559.

22. Maceiras, R.; Alfonsín, V.; Morales, F.J. Recycling of waste engine oil for diesel production. Waste Manag. 2017, 60, 351-356. [CrossRef] [PubMed]

23. Prabakaran, B.; Zachariah, Z.T. Production of fuel from waste engine oil and study of performance and emission characteristics in a diesel engine. Int. J. ChemTech Res. 2016, 9, 474-481.

24. Zandi-Atashbar, N.; Ensafi, A.A.; Ahoor, A.H. Nano- $-\mathrm{CeO}_{2} / \mathrm{SiO}_{2}$ as an efficient catalytic conversion of waste engine oil into liquid fuel. J. Clean. Prod. 2017, 166, 1010-1019. [CrossRef]

25. Aburas, H.; Bafail, A.; Demirbas, A. The pyrolizing of waste lubricating oil (WLO) into diesel fuel over a supported calcium oxide additive. Petrol. Sci. Technol. 2015, 33, 226-236. [CrossRef]

26. Petder. Waste Engıne O1l Management Project. Available online: http:/ / www.petder.org.tr/ (accessed on 19 February 2018).

27. Ori-Jesu, A.; Ori-Jesu, M. Biodegradation of mineral oils-A review. Afr. J. Biotechnol. 2009, 8, 915-920.

28. Fingas, M. Handbook of Oil Spill Science and Technology; John Wiley \& Sons.: Hoboken, NJ, USA, 2015. [CrossRef]

29. Çaynak, S.; Gürü, M.; Biçer, A.; Keskin, A.; Içingür, Y. Biodiesel production from pomace oil and improvement of its properties with synthetic manganese additive. Fuel 2009, 88, 534-538. [CrossRef]

30. Gürü, M.; Artukoğlu, B.D.; Keskin, A.; Koca, A. Biodiesel production from waste animal fat and improvement of its characteristics by synthesized nickel and magnesium additive. Energy Convers. Manag. 2009, 50, 498-502. [CrossRef]

31. Gürü, M.; Karakaya, U.; Altıparmak, D.; Alıcılar, A. Improvement of Diesel fuel properties by using additives. Energy Convers. Manag. 2002, 43, 1021-1025. [CrossRef]

32. Gürü, M.; Koca, A.; Can, Ö.; Çinar, C.; Şahin, F. Biodiesel production from waste chicken fat based sources and evaluation with $\mathrm{Mg}$ based additive in a diesel engine. Renew. Energy 2010, 35, 637-643. [CrossRef]

33. Keskin, A.; Gürü, M.; Altıparmak, D. Influence of metallic based fuel additives on performance and exhaust emissions of diesel engine. Energy Convers. Manag. 2011, 52, 60-65. [CrossRef]

34. Keskin, A.; Gürü, M.; Altiparmak, D. Biodiesel production from tall oil with synthesized Mn and Ni based additives: Effects of the additives on fuel consumption and emissions. Fuel 2007, 86, 1139-1143. [CrossRef]

35. Keskin, A.; Gürü, M.; Altiparmak, D. Influence of tall oil biodiesel with Mg and Mo based fuel additives on diesel engine performance and emission. Bioresour. Technol. 2008, 99, 6434-6438. [CrossRef] [PubMed]

36. Specifications of the Diesel Engine Generator. Available online: http://www.bobig.cn/HTML/Product/ Engine/BD186FA_FAE.html (accessed on 19 February 2018). 
37. Holman, J.P. Experimental Methods for Engineers; McGraw Hill Press: New York, NY, USA, 2001.

38. Lapuerta, M.; Rodríguez-Fernández, J.; Fernández-Rodríguez, D.; Patiño-Camino, R. Modeling viscosity of butanol and ethanol blends with diesel and biodiesel fuels. Fuel 2017, 199, 332-338. [CrossRef]

39. EN 590. Available online: http://www.envirochem.hu/www.envirochem.hu/documents/EN_590_2009_ hhV05.pdf (accessed on 19 February 2018).

40. Jakhrani, A.Q.; Othman, A.-K.; Rigit, A.R.H.; Samo, S.R. Estimation of carbon footprints from diesel generator emissions. In Proceedings of the 2012 International Conference on Green and Ubiquitous Technology, Miami, FL, USA, 7-8 July 2012; pp. 78-81.

41. Geng, P.; Cao, E.; Tan, Q.; Wei, L. Effects of alternative fuels on the combustion characteristics and emission products from diesel engines: A review. Renew. Sustain. Energy Rev. 2017, 71, 523-534. [CrossRef]

42. NguyenThi, T.X.; Bazile, J.-P.; Bessières, D. Density Measurements of Waste Cooking Oil Biodiesel and Diesel Blends over Extended Pressure and Temperature Ranges. Energies 2018, 11, 1212. [CrossRef]

43. Yusop, A.F.; Mamat, R.; Yusaf, T.; Najafi, G.; Yasin, M.H.M.; Khathri, A.M. Analysis of Particulate Matter (PM) Emissions in Diesel Engines Using Palm Oil Biodiesel Blended with Diesel Fuel. Energies 2018, 11, 1039. [CrossRef]

44. Da Silva Araújo, F.D.; do Nascimento Cavalcante, A.; Sousa, M.D.B.; de Moura, C.V.R.; Chaves, M.H.; Aued-Pimentel, S.; Fernandes Caruso, M.S.; Tozetto, L.J.; Kaline Morais Chaves, S. Biodiesel Production from Bombacopsis glabra Oil by Methyl Transesterification Method. Energies 2017, 10, 1360. [CrossRef]

(C) 2018 by the authors. Licensee MDPI, Basel, Switzerland. This article is an open access article distributed under the terms and conditions of the Creative Commons Attribution (CC BY) license (http://creativecommons.org/licenses/by/4.0/). 